\title{
Peningkatan Pengetahuan Kader Posyandu dalam Manajemen Laktasi Melalui Metode Ceramah di Kelurahan Rangkapan Jaya Kecamatan Pancoran Mas Kota Depok
}

\author{
Nurul Huriah Astuti \\ Program Studi Kesehatan Masyarakat, Fakultas Ilmu-Ilmu Kesehatan \\ Universitas Muhammadiyah Prof. Dr. HAMKA \\ email : nurul_taqia@uhamka.ac.id
}

\begin{abstract}
Knowledge Improvement of Posyandu Cadres in Lactation Management Through Lecture Method in Rangkapan Jaya Village, Pancoran Mas Sub-district, Depok City
\end{abstract}

\begin{abstract}
Introduction : Mother's Milk is the first food for babies and provides energy and nutrients not only for the first six months of life but also up to two years of age. Breastfeeding is one of the most effective ways to ensure the health and survival of the child. Indonesia Demographic and Health Survey 2012 states that the exclusive breastfeeding rate was $42 \%$ in Indonesia, $33.7 \%$ in West Java, and $61.36 \%$ in Depok City. This numbers need to be improved. One way is through health cadres in Posyandu as the front guard to improve public health status. This study aims to determine the effectiveness of lecture methods with such tools in improving knowledge about lactation management.

Methods : The subjects of this study were 24 health cadres at four posyandu in Rangkapan Jaya Village Pancoran Mas Sub-district Depok City. This type of research is quasi experimental with pre-test and post-test design.

Results : The results showed that $87.5 \%$ of respondents had improved knowledge after training with lecture and demonstration methods with props and emo-demo techniques. The average pre-test score was 85.88 and post-test score was 91.08. Respondents who had a range of knowledge score 90-100 were higher on post-test result (62.5\%) than pre-test result (29.2\%). The results of statistical tests showed that there was difference of cadres knowledge between before and after being given lactation management training through lecture and demonstration methods with props and emo-demo techniques $(p=0.004)$.

Conclusions : The results showed that $87.5 \%$ of respondents had improved knowledge after training with lecture and demonstration methods with props and emo-demo techniques. The results of statistical tests indicate that the methods performed effectively increase the knowledge of health cadres. Continuing education for posyandu health cadres through lecture and demontration methods with props and emodemo techniques can be an option.
\end{abstract}

Keywords : Breastfeeding, health cadres, lecture method

\section{PENDAHULUAN}

Menyusui adalah satu satu dari cara yang paling efektif untuk menjamin kesehatan dan kelangsungan hidup anak (WHO, 2015). Setiap anak yang disusui dalam waktu empat jam setelah lahir dan diberikan hanya air susu ibu dalam enam bulan kehidupannya, kemudian melanjutkan menyusu hingga usia dua tahun maka peluang hidup pada tahun pertama lebih besar (WHO, 2015). World Health Organization (WHO, 2015) menyebutkan 800.000 anak setiap tahunnya di dunia dapat diselamatkan pada tahun pertama kehidupannya karena ASI.

Air Susu Ibu adalah makanan pertama untuk bayi dan menyediakan energi dan nutrien bukan hanya untuk enam bulan pertama kehidupan bayi, tetapi juga hingga usia dua tahun. Air Susu Ibu menyediakan lebih dari setengah kebutuhan energi anak usia enam sampai 12 bulan dan menyediakan kebutuhan energi pada anak usia 12 sampai 24 bulan. Air Susu Ibu juga merupakan sumber energi dan protein selama anak sakit dan dapat menurunkan kematian pada anak-anak yang mengalami kurang gizi (WHO, 2016). Anak-Anak dan remaja yang mendapatkan Air Susu Ibu sejak bayi lebih kecil kemungkinan untuk overweight atau kegemukan. Selain itu, anak-anak dan remaja yang mendapatkan Air Susu Ibu lebih baik hasil tes intelegensianya dan lebih tinggi partisipasi sekolahnya (WHO, 2016). Dari sisi ibu, menyusui juga berkonstribusi pada kesehatannya, seperti menurunkan risiko kanker ovarium dan kanker 
payudara dan dapat menolong menjarangkan kehamilan karena menyusui eksklusif sampai bayi di bawah enam bulan akan memiliki efek hormonal yang mempengaruhi tidak datangnya menstruasi (WHO, 2016).

Sayangnya, banyak bayi dan anak-anak tidak cukup optimal mendapatkan Air Susu Ibu. Secara global, sekitar $43 \%$ dari bayi usia 0-6 bulan disusui secara eksklusif, yaitu tidak diberikan makanan atau minuman apapun kecuali Air Susu Ibu (WHO, 2016). Sementara di Indonesia, angka menyusui eksklusif menurut Survei Demografi dan Kesehatan Indonesia (SDKI) 2012 mencapai $42 \%$. Angka tersebut sudah mengalami kenaikan dibandingkan tahun 2007 sebesar 32\% (Kemenkes, 2014). Angka tersebut, tidak jauh berbeda dengan angka secara global. Sedangkan di Jawa Barat, menurut laporan Dinas Kesehatan Provinsi, angka menyusui eksklusif di provinsi tersebut tahun 2013 adalah sebesar 33,7\% (Kemenkes, 2014). Di Kota Depok, angka menyusui eksklusif sebesar 61,36\% (Depokpos, 2016). Angka ini sudah lebih tinggi dibandingkan angka global, nasional, maupun provinsi. Namun demikian, masih perlu ditingkatkan agar manfaat dan keuntungan dari pemberian Air Susu Ibu selama enam bulan pertama kehidupan bayi dapat dirasakan oleh semua bayi-bayi yang lahir di kota Depok. Untuk itu, promosi secara aktif tentang Air Susu Ibu sebagai zat gizi utama bayi hingga usia dua tahun disertai dengan manajemen laktasi yang efektif perlu terus ditingkatkan. Konseling yang adekuat dan dukungan utama pada ibu dan keluarga secara optimal akan meningkatkan keberhasilan menyusui pada ibu-ibu yang memiliki bayi (WHO, 2015). Dukungan tersebut bisa berasal dari profesional di bidang kesehatan ataupun dari para pekerja sosial di bidang kesehatan dan sukarelawan (McFadden A, et al., 2017). Di Indonesia, pekerja sosial di bidang kesehatan, di antaranya, dikenal sebagai kader posyandu.

Posyandu atau Pos Pelayanan Terpadu adalah salah satu bentuk upaya kesehatan bersumber daya masyarakat yang dilaksanakan oleh, dari, dan bersama masyarakat untuk memberdayakan dan memberikan kemudahan kepada masyarakat guna memperoleh pelayanan kesehatan bayi ibu, bayi, dan anak balita (Kemenkes, 2012). Dalam pelaksanaannya, peran kader memiliki peranan penting. Peran kader kesehatan posyandu di antaranya adalah mengajak keluarga untuk mendorong ibu dalam memberikan Air Susu Ibu secara eksklusif agar bayi tumbuh sehat dan memberikan edukasi pada ibu hamil dan ibu pasca persalinan tentang menyusui (Kemenkes, 2012). Dengan demikian, untuk menjalankan tugas tersebut, kader posyandu harus dibekali dengan pengetahuan dan ketrampilan yang benar tentang manfaat dan metode efektif menyusui agar dapat membimbing ibu hamil, ibu pasca persalinan, dan ibu menyusui untuk berhasil dalam menyusui hingga usia anak dua tahun.

Kader-kader kesehatan di Posyandu Kelurahan Rangkapan Jaya Kecamatan Pancoran Mas Depok belum pernah mendapatkan pelatihan khusus tentang manajemen laktasi, yaitu segala daya upaya yang dilakukan untuk membantu ibu mencapai keberhasilan dalam menyusui bayinya. Padahal, mereka aktif berperan di setiap hari posyandu dan bertemu dengan ibu-ibu hamil dan menyusui. Sementara manajemen laktasi menjadi suatu hal yang penting untuk diketahui oleh ibu hamil dan menyusui untuk mencapai keberhasilan menyusui. Untuk mengatasi permasalahan tersebut, diperlukan strategi promosi kesehatan dengan metode yang tepat sehingga informasi yang diterima dapat meningkatkan pengetahuan dan pemahaman kader kesehatan tentang manajemen laktasi. Oleh karena itu, peneliti tertarik untuk melakukan upaya pemberian pengetahuan dan pemahaman kepada kader kesehatan di Posyandu kelurahan Rangkapan Jaya Kecamatan Pancoran Mas menggunakan metode ceramah dengan alat bantu peraga bayi dan peraga payudara, dan teknik emo-demo (emotional demonstration), yaitu kegiatan demonstrasi dengan menggunakan kekuatan emosional, untuk memperkenalkan kapasitas lambung bayi berdasarkan usia bayi.

Berdasarkan hal tersebut, peneliti ingin mengetahui efektivitas metode ceramah dengan alat bantu tersebut dalam meningkatkan pengetahuan tentang manajemen laktasi pada kader kesehatan di Posyandu Kelurahan 
Rangkapan Jaya Kecamatan Pancoran Mas Kota Depok.

\section{METODE}

Populasi penelitian ini adalah semua kader kesehatan yang ada di empat posyandu yang ada di Kelurahan Rangkapan Jaya Kecamatan Pancoran Mas Kota Depok, yaitu Posyandu Kurma, Posyandu Anggur, Posyandu Apel A-B, dan Posyandu Belimbing. Adapun subyek penelitian ini adalah kader empat posyandu di Kelurahan Rangkapan Jaya Kecamatan Pancoran Mas Kota Depok tersebut yang terpilih mengikuti pelatihan sejumlah 24 orang. Lokasi penelitian dilakukan di Posyandu Kurma Kelurahan Rangkapan Jaya Kecamatan Pancoran Mas Kota Depok. Jenis penelitian ini adalah penelitian eksperimen semu atau Quasi experimental dengan rancangan pre-test dan post-test.

Penelitian ini dilakukan pada tanggal $24 \mathrm{Mei}$ 2017. Responden dalam penelitian ini diberikan pre-test selama 20 menit dan kemudian dilanjutkan dengan pemberian ceramah dan demonstrasi dengan alat peraga dan pendekatan emo-demo selama tiga jam dengan jeda 10 menit. Materi pelatihan sesi pertama adalah 1001 tentang Air Susu Ibu dan sesi kedua tentang cara kerja menyusu. Penceramah adalah Magister Kesehatan
Masyarakat yang telah mengikuti pelatihan manajemen laktasi dan memiliki sertifikat sebagai konselor menyusui dari Perhimpunan Perinatologi Indonesia (Perinesia). Setelah ceramah dan demonstrasi dengan alat peraga dan pendekatan emo-demo dilakukan, kemudian responden diberikan post-test selama 20 menit. Soal pre-test dan post-test sama.

Analisis data dilakukan secara univariat dan bivariat. Uji $T$ berpasangan digunakan untuk mengetahui apakah ada perbedaan pengetahuan antara sebelum dan sesudah kegiatan tersebut dilakukan.

\section{HASIL}

Semua kader posyandu yang menjadi responden penelitian ini berjenis kelamin perempuan. Karakteristik responden berdasarkan umur menunjukkan bahwa umur termuda adalah 25 tahun dan tertua adalah 65 tahun. Lama menjadi kader, terlama adalah 15 tahun dan termuda adalah lima tahun. Responden berasal dari empat Posyandu di Kelurahan Rangkapan Jaya Kecamatan Pancoran Mas Kota Depok. Mayoritas responden berasal dari Posyandu Kurma dan Posyandu Apel A-B, masing-masing sebesar 37,5\% (Tabel 1).

Tabel 1 Distribusi Karakteristik Responden

\begin{tabular}{lccc}
\hline \multicolumn{1}{c}{ Variabel } & \multicolumn{1}{c}{ Kategori } & Jumlah & Persentase \\
\hline Umur & Termuda 25 tahun dan Tertua 65 tahun & \\
Lama Menjadi Kader & Terlama 15 tahun dan Termuda 5 tahun & \\
Jenis Posyandu & 1) Posyandu Kurma & 9 & 37,5 \\
& 2) Posyandu Apel A-B & 9 & 37,5 \\
& 3) Posyandu Belimbing & 2 & 8,5 \\
& 4) Posyandu Anggur & 4 & 16,7 \\
\hline
\end{tabular}

Instrumen penelitian untuk pre-test dan post-test berisi pertanyaan tentang manfaat ASI, kolostrum, Inisiasi Menyusui Dini (IMD), komposisi ASI, teknik menyusui, dan faktor keberhasilan menyusui. Ada 25 pertanyaan yang diberikan kepada responden. Setiap satu soal memiliki nilai skor 4, sehingga total nilai skor adalah 100.

Hasil penelitian menunjukkan ada 21 orang responden $(87,5 \%)$ yang mengalami peningkatan pengetahuan setelah pelatihan dengan metode ceramah dan demonstrasi dengan alat peraga maupun teknik emo-demo dilakukan. Rerata nilai pre-test adalah 85,88 dan rerata nilai post-test adalah 91,08 (Gambar 1). Perbandingan nilai pre-test dan post-test dengan menggunakan interval menunjukkan bahwa responden yang memiliki nilai pengetahuan 90 - 100 lebih banyak pada hasil post-test, yaitu sebesar $62,5 \%$ dibandingkan 29,2\% pada nilai pre-test (Tabel 2). 


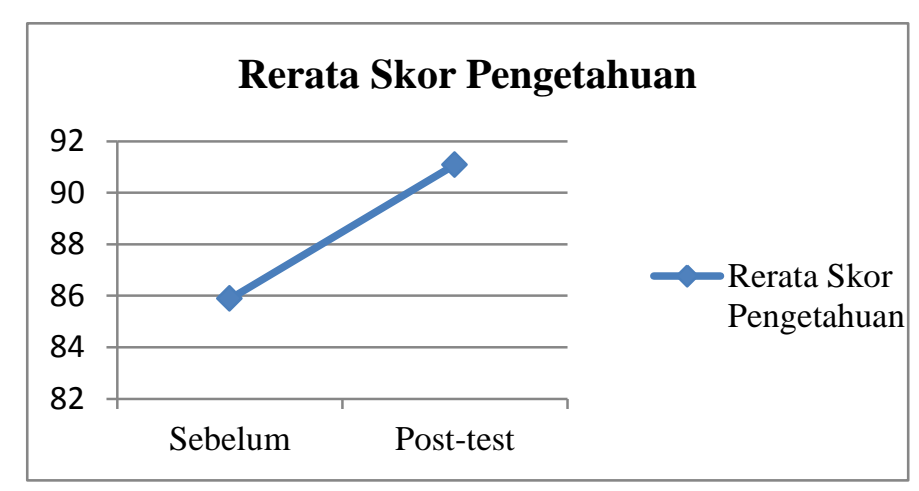

Gambar 1 Perubahan Rerata Skor Pengetahuan Antara Sebelum dan Sesudah Intervensi

Tabel 2.Skor Nilai Pre-test dan Post-test Pengetahuan Kader

\begin{tabular}{ccccc}
\hline & \multicolumn{2}{c}{ Nilai Pre-test } & \multicolumn{2}{c}{ Nilai Post-test } \\
\cline { 2 - 5 } Interval Nilai & Frekuensi & Persentase (\%) & Frekuensi & Persentase (\%) \\
\hline $70-79$ & 3 & 12.5 & 3 & 12,5 \\
$80-89$ & 14 & 58,3 & 6 & 25,0 \\
$90-100$ & 7 & 29,2 & 15 & 62,5 \\
\hline
\end{tabular}

Hasil uji statistik dengan menggunakan Uji $\mathrm{T}$ berpasangan diperoleh nilai $\mathrm{p}=0,004$ dengan alpha 0,05. Artinya terdapat perbedaan pengetahuan kader antara sebelum dan sesudah diberi pelatihan manajemen laktasi dengan metode ceramah dan demonstrasi dengan alat peraga serta teknik emo-demo. Dengan demikian disimpulkan bahwa intervensi dengan metode ceramah dan demonstrasi dengan alat peraga serta teknik emo-demo efektif meningkatkan pengetahuan kader kesehatan tentang manajemen laktasi.

\section{PEMBAHASAN}

Promosi kesehatan untuk mengubah perilaku dapat dilakukan dengan metode ceramah. Penelitian ini ingin memberikan pengetahuan pada kader kesehatan sehingga diharapkan kader kesehatan dapat membagi pengetahuannya dan mendampingi ibu hamil dan ibu menyusui yang datang ke posyandu tempatnya bertugas. Melalui pemberian pengetahuan dan pendampingan dari kader kesehatan maka ibu hamil dan menyusui dapat sukses menyusui.

Salah satu teknik dan metode promosi kesehatan pada kelompok besar (15-50 orang) yang efektif adalah dengan metode ceramah diikuti dengan atau tanpa diikuti oleh tanya jawab. Metode itu perlu diperkuat dengan bantuan slide projector dan sebagainya (Notoatmodjo, 2010).
Penelitian ini menunjukkan hasil yang sejalan dengan konsep promosi kesehatan tersebut. Hasil penelitian ini juga searah dengan penelitian Sarwani, et al (2010) yang menunjukkan bahwa pendidikan kesehatan tentang talasemia dengan metode ceramah meningkatkan pengetahuan kader kesehatan di Kecamatan Pekuncen dan Sumbang. Dalam penelitian Sarwani didapatkan ada $60,7 \%$ kader kesehatan meningkat pengetahuannya setelah promosi kesehatan melalui ceramah dilakukan. Penelitian Jouhari, et al. (2015) di Tehran, Iran juga menunjukkan bahwa metode pelatihan dan workshop dapat meningkatkan pengetahuan peserta tentang gempa bumi dan bagaimana menghadapinya. Penelitian mengenai pengaruh pelatihan pada pengetahuan kader kesehatan tentang pencegahan penyakit kardiovaskular dan gaya hidup sehat di dua kota di Iran juga menunjukkan hasil yang sama. Penelitian tersebut memperlihatkan bahwa intervensi melalui pendidikan, yaitu pelatihan dapat meningkatkan pengetahuan relawan kesehatan (kader kesehatan) tentang penyakit kardiovaskular dan perilaku gaya hidup (Roohafza, et al, 2014). Peningkatan pengetahuan kader kesehatan tersebut diperlukan bukan hanya untuk meningkatkan pemahaman mereka namun juga untuk memberikan pelayanan yang lebih berorientasi pada masyarakat. 


\section{KESIMPULAN}

Hasil penelitian ini memperlihatkan $87,5 \%$ kader kesehatan meningkat pengetahuannya setelah pelatihan dilakukan. Hasil uji statistik juga menyimpulkan bahwa metode pelatihan tersebut efektif dalam meningkatkan pengetahuan kader posyandu. Oleh karena itu, pendidikan berlanjutan bagi kader kesehatan di Posyandu, melalui metode ceramah dengan demonstrasi menggunakan alat peraga dan pendekatan emodemo dapat menjadi pilihan.

\section{UCAPAN TERIMAKASIH}

Terima kasih kami sampaikan ke LPPM Universitas Muhammadiyah Prof. HAMKA yang sudah memberikan dana hibah untuk melakukan kegiatan ini, juga kepada para kader, peserta pelatihan, dan mahasiswa-mahasiswa FIKES UHAMKA yang sudah membantu terselenggaranya kegiatan ini.

\begin{abstract}
ABSTRAK
Pendahuluan: Air Susu Ibu adalah makanan pertama untuk bayi dan menyediakan energi dan nutrien bukan hanya untuk enam bulan pertama kehidupan bayi, tetapi juga hingga usia dua tahun. Menyusui adalah salah satu cara yang paling efektif untuk menjamin kesehatan dan kelangsungan hidup anak. SDKI 2012 menyebutkan bahwa angka menyusui eksklusif mencapai 42\% di Indonesia, 33,7\% di Jawa Barat, dan $61,36 \%$ di Kota Depok. Angka ini perlu ditingkatkan. Salah satu caranya melalui kader kesehatan di Posyandu sebagai garda terdepan meningkatkan derajat kesehatan masyarakat. Penelitian ini bertujuan mengetahui efektivitas metode ceramah dengan alat bantu dalam meningkatkan pengetahuan tentang manajemen laktasi.

Metode: Subyek penelitian ini adalah 24 orang kader kesehatan di empat posyandu di Kelurahan Rangkapan Jaya Kecamatan Pancoran Mas Kota Depok. Jenis penelitian ini adalah penelitian eksperimen semu atau quasi experimental dengan rancangan pre-test dan post-test.

Hasil: Hasil penelitian menunjukkan ada 87,5\% responden mengalami peningkatan pengetahuan setelah pelatihan dengan metode ceramah dan demonstrasi dengan alat peraga maupun teknik emo-demo. Rerata nilai pre-test adalah 85,88 dan rerata nilai post-test adalah 91,08. Responden yang memiliki rentang nilai pengetahuan 90-100 lebih banyak pada hasil post test $(62,5 \%)$ dibandingkan hasil pre test $(29,2 \%)$. Hasil uji statistik menunjukkan terdapat perbedaan pengetahuan kader antara sebelum dan sesudah diberi pelatihan manajemen laktasi dengan metode ceramah dan demonstrasi dengan alat peraga serta teknik emo-demo ( $\mathrm{p}=0,004)$.

Kesimpulan: Hasil penelitian memperlihatkan $87,5 \%$ kader kesehatan meningkat pengetahuannya setelah pelatihan dilakukan. Hasil uji statistik juga menyimpulkan bahwa metode pelatihan efektif dalam meningkatkan pengetahuan kader posyandu. Oleh karena itu, pendidikan berlanjutan bagi kader kesehatan di Posyandu, melalui metode ceramah dengan demonstrasi menggunakan alat peraga dan pendekatan emo-demo dapat menjadi pilihan.
\end{abstract}

Kata Kunci: Menyusui, kader kesehatan, ceramah

\section{DAFTAR PUSTAKA}

1. Badan Pusat Statistik. (2013). Survei Demografi dan Kesehatan Indonesia (SDKI) 2012. Jakarta : Badan Pusat Statistik. Diakses dari http://chnrl.org/pelatihandemografi/SDKI-2012.pdf

2. Hariani, B. (2016). 61,36\% Wanita di Depok Sudah Berikan ASI Eksklusif. Depok Pos. Diakses dari http://www.depokpos.com/arsip/2016/12/6136-wanitadi-depok-sudah-berikan-asi-eksklusif/

3. Jouhari, Z., Pirasteh, A., Reza Ghassemi, G., Bazrafkan, L. (2015). The Effects of Educational Program on Health Volunteers' Knowledge Regarding Their Approach to Earthquake in Health Centers in Tehran. J Adv Med Educ Prof, 3(2), 56-61. Diakses dari

https://www.ncbi.nlm.nih.gov/pmc/articles/PMC44035 65/

4. Kementerian Kesehatan RI. (2012). Ayo Ke Posyandu Setiap Bulan. Jakarta : Kementerian Kesehatan RI. Diakses dari http://www.depkes.go.id/resources/download/promosikesehatan/buku-saku-posyandu.pdf

5. Kementerian Kesehatan RI. (2014). Situasi dan Analisis ASI Eksklusif. Jakarta : Kementerian Kesehatan. Diakses dari http://www.depkes.go.id/resources/download/pusdatin/ infodatin/ infodatin-asi.pdf

6. McFadden, A., et al. (2017). Support for Healthy Breastfeeding Mothers with Healthy Term Babies. Cochrane Database of Systematic Reviews, 2. DOI: 10.1002/14651858.CD001141.pub.5

7. Notoatmodjo, S. (2010). Promosi Kesehatan, Teori dan Aplikasi. Jakarta : Rineka Cipta.

8. Roohafza, H., Khani, A., Sadeghi, M., Bahonar, A., Sarrafzadegan, N. (2014). Health Volunteers, Knowledge of Cardiovascular Disease Prevention and Healthy Lifestyle Following a Community Trial: Isfahan Healthy Heart Program. J Educ Health Promot, 3: 59. DOI: 10.4103/2277-9531.134761. Diakses dari 
https://www.ncbi.nlm.nih.gov/pmc/articles/PMC41139 89/

9. Sarwani Dwi, SR., Nurhayati, N., Supriyanto. (2014). Efektifitas Ceramah terhadap Pengetahuan Kader Kesehatan tentang Penyakit Talasemia di Kecamatan Pekuncen dan Kecamatan Sumbang Kabupaten Banyumas. KESMAS, 8 (1), 29-35. Diakses dari http://dx.doi.org/ 10.21109/kesmas.v11i1
10. World Health Organization. (2015). 10 Facts of Breasfeeding. Diakses dari http://www.who.int/features/factfiles/breastfeeding/en/

11. World Health Organization. (2016). Infant and Young Child Feeding. Diakses dari http://www.who.int/mediacentre/factsheets/fs342/en/ 